\title{
Research on Economics of Legal System of Environmental Regulations
}

\author{
Jia Zuo \\ Liaoning Provincial Party School of the Communist Party of China \\ Shenyang, China
}

\begin{abstract}
The legal system of environmental law in our country is constituted of environmental regulations in constitution and environmental regulations represented by special normative environmental legal documents. The theories in legal system of environmental regulations are indispensable to understand environmental law and regulations. The legal system of environmental regulations with organic connection is established to adjust and control relations of environmental regulations and to control environment through law. In this paper, environmental regulations are researched, and the problems in legal system of environmental regulations and reform thinking are discussed.
\end{abstract}

Keywords-environmental regulations; legal system; pollution control; perfection of the law

\section{INTRODUCTION}

Environmental problems refer to the phenomenon that human activities or natural causes make the environment have adverse changes that influence human production and life and bring disasters for human. From the perspective of economics, environmental pollution is essentially a typical negative external problem. Objectively, market failure caused by the solution of external problems like environmental pollution needs government to take direct or indirect measures to regulate the environment, in order to protect the environment required by human in existence and development.

Environmental regulations bring environmental problems in legal norms. Law avails environmental regulations and sustainable development because it influences economic behaviors and governmental regulation. Under the background of globalization of environmental problems, in order to guarantee and improve social public welfare, government should base on interests of the general public, alleviate and solve environmental problems through environmental law, and effectively prevent and curb environmental pollution.

\section{THEORETICAL ANALYSIS ON LEGAL SYSTEM OF ENVIRONMENTAL REGULATIONS}

Balance of law supply and demand means law supply conforms to law demand without surplus and shortage, and get maximum net earning in legal projects without "potential income" and the requirement of further institutional change, reaching "Pareto Optimum".

\section{A. Source of Environmental Problems}

Environmental degradation is the product of independent decision-making of one billion users of environmental resources and decisive factors of these decision-makings. Market failure is embodied in externality related pollution, resource development and destruction of ecosystem.

1) Externality: Externality is an important source of market failure and the basic theory used by explain causes of environmental problems. Externality is the most basic concept in environmental economics. Environmental problems are typical embodiment of negative externality, which makes the number of market production larger than that of social consensus.

2) Public goods: As a public good, environmental resources are non-exclusive. Numerous free riders consume environmental resources. Because public sectors have the right to manage goods through taxation and collecting other expenses, the free rider problem can be solved by the government through taking collective actions to supply the system of environmental resources.

\section{B. Economic Analysis of Environmental Problems}

System roots of environmental problems come from "market failure" and "government failure", which constitute "system failure".

1) Market's function failure:Because environmental pollution directly reduces people's living quality, it is disgusting public good. As the public good and labor service that provides collective interests for the society, environmental protection is consumed by collectives and has strong positive external effects. Market mechanism leads to insufficient supply of ecological construction and environmental protection and sometimes leads to zero supply.

2) Government's function failure:"Government's function failure" of environmental problems includes nonintervention when it needs government intervention, and excessive intervention when government intervention isn't required. The former includes the government fails to 
regulate environmental natural monopoly, and the delimitation of property rights of ecological and environmental resources is nonstandard; the latter includes random intervention of market price through restriction of price twists price mechanism of the market. In general, "government's function failure" of environmental problems includes government policy failure and environmental management failure.

\section{Analysis on Necessity of Environmental Regulations}

Means of environmental regulations include legal means and nonlegal means. Legal means refers to the method that depends on legal institutions and mandatory law to manage environmental economic activities in accordance with legal norms. Essentially, legal means is strictly mandatory and sanctionative because it adjusts relations of environmental economic activities through authority of law. Undeniably, at present, the application of economic means based on market is increasing. Legal means still plays a dominant role in policy choice, while economic means is seldom used and often supplements legal means.

\section{Analysis on Constitution and Functions of Legal System of Environmental Regulations}

Theoretical regulation of legal system classifies and combines legal departments according to principles and criteria, at the same time controls related legal systems according to logic chain of induction-deduction, and guides formulation, applicability and improvement of law.

1) Constitution of legal system of environmental regulations: Legal system of environmental law of our country consists of environmental laws and regulations structurally; its concrete contents consist of environmental laws and regulations that adjust social relations of the same type, namely environmental legal relation.

2) Functions of legal system of environmental regulations: The research on legal system is to understand it through decomposing law into elements. Understanding elements of law is to understand law. Integrating elements of law into systematic legal system is another way to understand law.

\section{CURRENT SitUATION OF LEGAL SYSTEM OF ENVIRONMENTAL REGULATIONS, PROBLEMS AND REASONS IN CHINA}

From the perspective of economics of law, economic backwardness is caused by imbalanced supply and demand of law and inefficient arrangement of legal system. Inefficiency or failure of legal system is caused by: preference and limited reason of governor, rigidity of ideology, bureaucracy, conflict of group's interests and limitation of knowledge.

\section{A. Current Situation and Characteristics of Legal System of Environmental Regulations in China}

Establishment of legal system of environmental regulations begins late with specific historical background, in order to develop economy. The design and arrangement of environmental legal system serves economic development, so it has deficiencies inevitably.

The establishment of legal system of environmental protection is the foundation of environmental regulations. Basic law of environmental protection occupies the key status. Its effective implementation directly influences environmental protection. Sound legal system of environmental protection should surround environmental basic law and consist of legislation related to prevention of environmental pollution. Environmental law shall subordinate to basic law of environmental protection, including legal system of prevention (Law on Environment Impact Assessment), legal system of prevention of environmental pollution and legal system of environmental punishment. At present, the complete legal system of environmental regulations hasn't been established in our country.

\section{B. Problems in Legal System of Environmental Regulations in China}

1) Absence of environmental administrative organization law: The Environmental Protection Act stipulates the environmental protection responsibility of competent government departments of environmental protection instead of governments at all levels. It diminishes responsibilities of governments, weakens environmental law enforcement and leads to random decision-making of governments. With the absence of environmental administrative organization law, the environmental public powers of central and local authorities are imbalanced obviously.

2) Weakened function of basic law of environmental protection: First, the historical background of production of Environmental Protection Act makes it restricted. The Act fails to take sustainable development as guiding thought to protect environmental resources and prevent environmental pollution. Second, the Environmental Protection Act lacks construction of market mechanism of environmental resources and has some regulations related to the planned economic system, failing to meet requirements of market economic system. Finally, the Environmental Protection Act has careless normative design and weak system construction, having been unable to deal with increasingly severe environmental pollution and economic damage.

3) Limited effects of environmental punishment law: Environmental criminal law brings little effects in solving environmental problems and containing environmental crimes because of the absence of proper environmental ethics. Law enforcement is improper because ethical ideas and ethical conducts of law-executors and the public cannot meet the demands of environmental protection. More importantly, the basis of law enforcement, namely environmental criminal legislation has fundamental defects.

4) Low status of cyclic social law: On the whole, cyclic social law of our country is at initial stage. Many aspects 
have absence of legislation. The quality of existing cyclic social law needs improvement. At present, the biggest barrier is that the pricing mechanism of resources is unreasonable to meet demands of development in market economy. Enterprises lack internal impetus in energy-saving and cost-reducing as well as pollution prevention.

\section{Economic Reasons for Problems in Legal System of Environmental Regulations}

First, the conflicts between interests of government sectors and environmental interests: Government sectors are called "economic man" and have independent interests. The concept of political achievements is typical manifestation of governmental interests. Second, great differences between pollution discharge cost and external cost of pollution: Marginal social cost of most pollution emitters is still higher than marginal private cost, namely charge system of pollution discharge lags far behind the original intention of pigovian tax. Third, inefficiency of incentive mechanism and improper government intervention: Chinese law is restricted by physical truth, so attentions must be paid to the limits of government intervention. Mandatory enforcement many not produce effects, even at cross purposes.

\section{COMPARISON OF LEGAL SYSTEM OF ENVIRONMENTAL REGULATIONS IN AMERICA, EUROPEAN UNION AND JAPAN AND REFERENCE}

Environmental legal systems in America, European Union and Japan are typical and can be called as epitome of legal system of environmental regulations in the world. Indepth research on the development of legal system of environmental regulations in developed countries and areas has referential and enlightenment significance on our country.

\section{A. Characteristics of Legal Systems of Environmental Regulations in America, European Union and Japan}

1) America legislates by Use of market means as Well as cost and benefit analysis:For the establishment of legal system of environmental regulations in America, the market means as well as cost and benefit analysis is used. The biggest topic in American environmental policy is the reform of environmental regulations. When regulations with major economic effects are formulated and released, regulation improvement act that requires overall evaluation on costs, benefits and risks is proposed.

2) Legislation of the European Union balances law coordination and joint action between countries: Legal system of environmental regulations in European Union balances law coordination and joint action between countries. Attentions are paid to relations between environmental regulations and international trade. Environmental standards have the same force with environmental law and follow the same legislative procedure. Environmental overall action plan of European Union refers to the legal document with high level and has special legal status even law-making function.
3) Japan devotes to establishing the system of cyclic social law: Legal system of environmental regulations in Japan forms the system of cyclic social law. Under the Basic Law of Environment, the cyclic social legislation system includes one basic law, two comprehensive laws and six individual laws, which promote the establishment and development of recycling society.

\section{B. Refer To Legal Systems of Environmental Regulations in America, European Union and Japan}

The enforcement of law needs specific historical background and social conditions like politics, economy and culture. At present, the era of development and characteristic social atmosphere in China determine the effects of law. Prior to referring ideas and achievements at abroad, we must research local conditions of law. China prefers compulsory means to economic means. Although the effects are limited, specific social factors in China cannot be ignored. Economic means has advantages that compulsory means doesn't have, and large potential and space for application. Without the support of proper social environment and legal system, both economic means and compulsory means cannot achieve results. Formulation of environmental policies is not to make choice between economic means and compulsory means. It often combines the two to better meet requirements in feasibility of effectiveness, fairness and politics. On legislation method, the economic analysis method of cost and benefit will avail the establishment of legal system of environmental regulations in China.

\section{RESEARCH ON STRATEGIES TO IMPROVE CHINESE LEGAL SYSTEM OF ENVIRONMENTAL REGULATIONS}

\section{A. Change Idea of Legislation in Environmental Regulations}

Guiding concept is explicit: coordination and sustainability, acceleration of protection: "Coordination and sustainability" emphasizes we shall envisage the "history of honor or disgrace" of economy and environment to seek proper solution; "acceleration of protection" requires us to strengthen sense of urgency and responsibility because the environmental protection in China develops slowly, and many basic systems haven't been established. Determine principles of establishing system: strengthen regulations and adjust means: the first is "strengthen regulations"; the second is "common responsibility"; the third is "planning and preservation"; the fourth is "combination of means"; the fifth is "localization of systems".

\section{B. Improve Legislative Procedure of Environmental Regulations}

To enforce environmental law of China, we must realize the "localization" of environmental regulations. Formulation of environmental law shall value legislative spirit instead of being under the guidance of the most stringent law. And it should be purposed to balance the ability of enterprises in law enforcement and the acceptable level of the public. Localization of legislation of environmental regulations in China must reconstruct the formulation process of 
environmental regulations: policy planning, legislation plan, protocol research, hearing of witnesses, final legislation and policy marketing.

\section{Improve Legal System of Environmental Regulations}

Legal system of environmental regulations is the core of legislation of environmental regulations. Whether it is integral and comprehensive and has compact connection determines effects and direction of legislation of environmental regulations. Legal system of environmental regulations in China can be established through:

1) Establish environmental administrative organization law: Organizations of environmental management are main part of legal system of environmental regulations. Without guarantee of explicit provisions of law, the regulations will be random and its regulations status will be influenced, directly damaging the regulation capacity of system.

2) Strengthen basic law of environmental protection: The modification of Environmental Protection Act shall conform to "comprehensive environmental basic law". First, legislative intent of Environmental Protection Act can be determined through modern concept of environmental ethics; second, strengthen governments' functions of environmental protection and establish systems about it; third, combine environmental administrative guidance mechanism with participation of the public in environmental protection and actively implement environmental democracy.

3) Enforce environmental protection law: Environmental impact assessment is often regarded as means for self-restraint of developers and is systematized for administrative organs to construct means of project management and supervise development activities. The understanding greatly reduces the effects of environmental impact assessment in social life and its status in environmental legal system. In order to change the situation, we must first implement public participation of environmental impact assessment; second, raise the status of judicial power in environmental impact assessment; last, improve legal system of strategic environmental evaluation.

4) Improve control act of environmental pollution: The development of control act of environmental pollution in China has "path dependence", namely depending on compulsory means. In order to achieve targets of environmental protection policy and sustainable development, the government must levy the tax from pollution emitters through economic means and make the costs internalized, in order to transform economic growth patterns and solve environmental protection.

5) Make orientation of environmental punishment law: Environmental punishment shall base on the fundamental objective of "punish and prevent crimes and protect human rights" determined by special property of criminal law, and embody the above legislative intents of environmental act at the meantime break the limitation of traditional theories of criminal law. The purpose is "to punish and prevent environmental crimes, prevent and remedy pollution and other public hazards, improve human health, maintain overall interests of ecosystem and promote the harmony between human and environment".

6) Improve cyclic social law: First, improve governments' responsibilities in developing recycling economy. Governments shall guide recycling economy and organically combine administrative means like administrative control, administrative guidance and economic incentive. Second, the system to extend responsibilities of producers is established. We should classify product category and make subject of liability in waste recovery clear; determine scope of application for extension of producers' responsibilities; determine forms to extend producers' responsibilities; improve organizations to extend producers' responsibilities. Third, participation and responsibilities of public consumers are improved. We have the rights to enjoy healthy environment and the responsibilities to improve and protect the environment. Responsibilities of public consumers can be improved in legislation through: clarify responsibilities of consumers in recycling product wastes; entitle the public to participate the legislation on circular economy and supervise legislation enforcement; advocate green consumption and exchange of old things.

\section{CONCLUSION}

To sum up, no matter we take what kind of regulation means and how we improve legal system, in order to solve the problem of environmental protection, we must adjust economic or industrial policies and systems and reflect on the relations between human and environment.

\section{REFERENCES}

[1] Alanen L. The Impact of Environmental Cost Internalization of Sectional Competitiveness: A New Conceptual Framework[J], UNCTAD Discussion Paper, and No.119. 1996: 22-34

[2] Babier, E. and Patrick Hultberg. Economic Integration, Environmental harmonization and Firm Relocation[J], University of Wyoming working paper. 2001: 44-67

[3] Birdsall, N. Wheeler, D. Trade Policy and Industrial pollution in Latin America: Where are the Pollution Havens? [J] In: World Bank Discussion Paper, 159. World Bank, Washington, DC. 1992:57-78

[4] Boumol, W. and Oates, W. The Theory of Environmental Economics[M]. Cambridge, Massachusetts: Cambridge University Press. 1989:27-32

[5] Buses, J. Trade, Environmental Regulations and the World Trade Organization: New Empirical Evidence[J], Journal of International Economics, 38(2), 2004:285-306.

[6] Charu Sharma. Environment Versus Development: The Long Valley Case[J], Journal of Chinese and Comparative Law 20012002. 2002:55-67

[7] Chrisman and Taylor. Globalization and the Environment: Determinants of Firm Self-Regulation in China [J]. Journal of International Business Studies, 32(3). 2001: 33-46

[8] Clifford Rechtschaffen \& David L. Markell, Reinventing Environmental Enforcement \& the State/Federal Relationship [M]. Environmental Law Institute. 2003: 21-42 
[9] Clifford Rechtschaffen \& Eileen Gauna. Environmental Justicelaw, policy, and regulation $[\mathrm{M}]$. Carolina Academic Press. 2001:45-47

[10] Dasgupta. Environmental Regulation and Development [M]. World Bank, Washington, DC: World Bank. 1995: 24-35

[11] Daniel J. Fiorino, The New Environmental Regulation [M], The MIT Press Cambridges, Massachusetts, London, England. 2006: 43-47

[12] Directive 76/464 on Pollution Caused by Certain Dangerous Substances Discharged into the Aquatic Environment of the Community, OJ 1976 L. 129/23.

[13] Directive 78/319 on Toxic and Dangerous Waste, OJ 1978 L 84/43, later amended.

[14] Directive 79/409 on the Conservation of Wild Birds, OJ 1979 L $103 / 1$, later amended.

[15] Directive 82/501 on the Major-accident Hazards of Certain Industrial Plants, OJ 1982 L 230/1, later amended.

[16] Directive 82/884 on a Limit Value for Lead in the Air.

[17] Directive 84/360 on the Combating of Air pollution from Industrial Plants, OJ 1984 L 188/20, later amended.

[18] Directive 93/76 to Limit Carbon Dioxide Emissions by Improving Energy Efficiency, OJ 1993 L 237/28.

[19] Ekins, P. The Kuznets curve for the environment and economic growth: examining the evidence [J]. Environmental Planning 29. 1997: 805-836 